\title{
Sweet Potato (Ipomia Batatus) Varieties Evaluation in Borana Mid Altitude
}

\author{
Desalegn Regassa ", Addis Shiferaw, Wakene Tigre \\ Oromia Agricultural Research Institute, Yabello Pastoral and Dry-Land Agriculture Research Center, Yabello, Ethiopia
}

\section{Email address:}

amensisa.regassa@gmail.com (D. Regassa)

\section{To cite this article:}

Desalegn Regassa, Addis Shiferaw, Wakene Tigre. Sweet Potato (Ipomia Batatus) Varieties Evaluation in Borana Mid Altitude. Science Research. Vol. 3, No. 5, 2015, pp. 248-251. doi: 10.11648/j.sr.20150305.12

\begin{abstract}
Sweet potato is one of the most important root and tuber crop for food and feed value. Borana mid altitudes in general and abaya woreda in particular are among the important sweet potato growing regions in southern Ethiopia. However, seeds of improved sweet potato varieties are either unavailable or inadequate. Therefore, the objective of this research is to test a range of improved varieties under Borana condition to identify genotypes with relatively better performance. To this effect, six improved and recommended varieties of sweet potato (Awassa 83, Beletech, Belela, Temesgen, Kulfu and Tula) were brought from Awassa research center and tried for their adaptation at Abaya woreda samara site with local variety in RCBD with three replications in 2014 and 2015 years. The result showed that the local variety is superior in yield and yield components in both years. The local variety gives average marketable fresh yield 111ton ha-1 with a yield advantage of about 77 ton ha-1over the highest yielded improved variety, Awassa 83, which gives about 34 ton ha-1. Therefore it is concluded that the farmers of Borana mid altitudes can continue to produce their local variety until superior variety will be developed for their specific area. Cultivar collection and screening activities can be suggested to develop suitable varieties for the area.
\end{abstract}

Keywords: Sweet Potato, Variety Evaluation, Borana

\section{Introduction}

Sweet potato is a member of convolvulaceae family, genus Ipomia and species batatus (Purselglove, 1972). It is accepted that the cultivated sweet potato has originated in Central America or tropical South America. Globally it is grown in an area of about 9.26 million hectares with a production of 126.18 million tons; average productivity being 13.6 ton $\mathrm{ha}^{-1}$ (Woolf, 1992). Sweet potato is one of the most important root and tuber crop for food and feed value. It is one of the twelve principal plant species utilized as a human feed throughout the world. It can be cultivated in many different climatic conditions; and as a result large areas of sweet potato are cultivated in Asia, Africa, Europe, America and Oceania (Paneque Ramirez, 1991). Seasonal food shortage is amongst the principal problems of farmers in mid-altitude areas of Southern Ethiopia. In some of the world's poorest nations, taro and sweet potato are important part of food security packages (Yared Dagne, 2014). Ethiopia ranks fifteenth in the world in terms of sweet potato production (Dan et al, 2013). It has been cultivated as crop in Ethiopia for several years and over $95 \%$ of the crop produced in the country is grown in south, south western and eastern parts of the country, where it has remained for centuries as an important staple for the community (Emanna, 1990). In Ethiopia sweet potato ranks the first in total production (42.84\%) and the second in area coverage $(25.43 \%)$ next to Irish potato from root and tuber crops cultivated (CSA 2014). Its root is used as food and feed. As food the root is usually consumed in boiled form. It is one of the cheapest sources of vitamin A. It is tolerant to adverse conditions like drought. It is an attractive food crop among farmers because it requires less care and input (CIP, 1995). It is a popular food in many parts of Eastern Africa. It is drought resistant, hardy and can grow in marginal areas, thus contributing to improved food security. The young leaves and vines can be consumed as vegetables or fed to livestock (CTA 2007).

Generally Sweet potatoes productivity is law under farmer condition due to many factors one of which will be lack of improved varieties. Endale et.al 1994 indicated that yield in farmers field is low mainly because of unavailability of improved genotypes and poor agronomic practices. The average yield ha-1 of sweet potato in Ethiopia is 33.74 ton ha ${ }^{-1}$ (CSA 2014). One of the main constraints among others in increasing yield $\mathrm{ha}^{-1}$ is lack of varieties of the crop which is 
adapted to specific condition of the area. Therefore developing and making available adaptable, high yielding and pest and disease tolerant varieties of Sweet potato is a priority concern in its productivity increase strategy.

\section{Materials and Methods}

\subsection{Description of Study Area}

The experiment was conducted at Abaya woreda samara site, in southern Ethiopia. The site is located at N06.43520 and E038.25425 with altitude of 1442 m.a.s.l.The soil at the site is characterized as sandy clay loam with $\mathrm{PH}$ of 5.68. The livelihood of the people of the zone is mostly pastoral and agro-pastoral (Dajane Takele, 2015).

\subsection{Planting Materials and Experiment Methodology}

Six improved and recommended varieties of sweet potato (Awassa 83, Beletech, Belela, Temesgen, Kulfu and Tula) were brought from Awassa research center and tried for their adaptation with local variety in RCBD with three replications in 2014 and 2015 years with the objective to identify Sweet potato varieties that is better in yield and other agronomic characteristics. Six rows with recommended spacing of $20 \mathrm{~cm}$ between plant and $70 \mathrm{~cm}$ between rows were followed. No fertilizer and other chemicals were applied to this experiment.

\subsection{Data Collection and Statistical Analysis}

Data were collected on parameters like average root number per plot, total fresh weight per hectare, marketable fresh weight per hectare, unmarketable fresh weight per hectare, dry weight per hectare, average root diameter and average root length. Diseased, deformed and tubers with a weight of less than 100gram were recorded as unmarketable. Analysis of variance for the collected parameters was performed as per the methods described by Gomez and Gomez (1984) using SAS computer software (SAS, 2009) for randomized complete block design (Table 1) and treatment mean comparison is done by Fisher's list significance difference (LSD) at 5\%.

\section{Result and Discussion}

The result of ANOVA showed that there is significant variation between varieties for yield and other parameters collected (Table 1). Tesfaye T. et.al 2011, also reported significant variation between sweet potato genotypes in yield and other desirable traits in their adaptation trial in different agro ecologies of Ethiopia. Mean marketable yield varied from 4.6 ton ha-1 for kulfu variety to 111.06 ton ha-1 for local cultivar. The local cultivar is superior in yield and yield components in both years (Fig 1, Table 2 and 3). This superiority of local cultivar over previously released varieties may be due to 1) Those local cultivars were not included in collection and screening activities in previous variety development activities and/or 2) The agro ecology of this experimental area varies from other areas where national variety verification trials were conducted in the previous variety releasing process.

\section{Conclusions and Recommendation}

Sweet potato need to be cultivated as stable and food security crop to feed the ever increasing population of Ethiopia. To increase production and productivity appropriate varieties has to be looked for beside other agronomic and plant protection activities. In the present experiment, since the local variety is superior in performance as compared to the tried improved varieties, the farmers can continue to produce their local variety until superior variety will be obtained. Cultivar collection and screening activities can help in further development of superior varieties for this area. Other agronomic trials should be done for the success of production and productivity of sweet potato in the area. Nutrient content and other quality parameter analysis and also suitable post harvest management practices needs to be done to improve the quality and longtime use of the crop. Since the findings are based on only one location and two cropping season, further studies using combination of locations and seasons is required to generate more reliable information on performance of varieties across location.

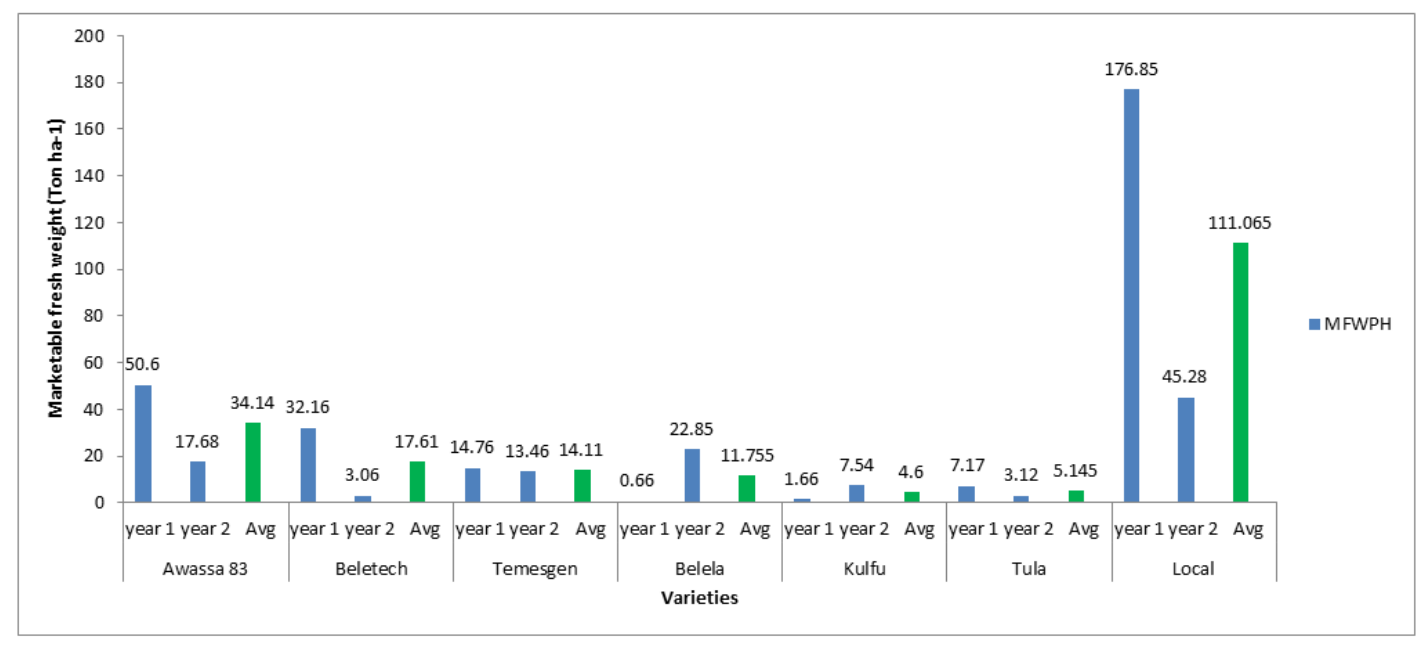

Fig. 1. Mean marketable fresh root yield (ton ha-1) of sweet potato variety adaptation trial at Abaya in 2014 and 2015 cropping season. 
Table 1. Mean squares due to Variety and error for yield, and yield related traits of sweet potato varieties grown in 2014 and 2015 at Abaya district samara site in Borana zone.

\begin{tabular}{|c|c|c|c|c|c|c|}
\hline \multirow[t]{4}{*}{ Traits } & \multicolumn{6}{|c|}{ Experimental years } \\
\hline & \multicolumn{3}{|c|}{ Year 2014} & \multicolumn{3}{|l|}{ Year 2015} \\
\hline & $\mathrm{Df}=2$ & $D f=6$ & $\mathrm{Df}=12$ & $\mathrm{Df}=\mathbf{2}$ & Df $=6$ & $\mathrm{Df}=12$ \\
\hline & Rep & Variety & error & Rep & Variety & error \\
\hline RNPP & $67.48 \mathrm{~ns}$ & $5888.71 * * *$ & 547.98 & $1334.33^{*}$ & $3798.64 * * *$ & 301.11 \\
\hline TFWPH & $15.62 \mathrm{~ns}$ & $161.68^{* * *}$ & 20.36 & $74.60 \mathrm{~ns}$ & $695.45 * * *$ & 43.47 \\
\hline MFWPH & $17.14 \mathrm{~ns}$ & $118.15^{* *}$ & 16.66 & $64.67 \mathrm{~ns}$ & $659.13 * * *$ & 42.58 \\
\hline UMFWPH & $0.04 \mathrm{~ns}$ & $3.80 * * *$ & 0.29 & $0.88 \mathrm{~ns}$ & $0.70 \mathrm{~ns}$ & 0.26 \\
\hline DWPH & $2.57 \mathrm{~ns}$ & $19.41 * * *$ & 2.47 & $9.03 \mathrm{~ns}$ & $71.25 * * *$ & 6.44 \\
\hline ARD & $243.20 \mathrm{~ns}$ & $395.34 *$ & 121.32 & $293.37 *$ & $71.96 \mathrm{~ns}$ & 51.17 \\
\hline ARL & $10.66 \mathrm{~ns}$ & $26.84 * *$ & 4.36 & $15.62 \mathrm{~ns}$ & $67.68 *$ & 21.35 \\
\hline
\end{tabular}

Ns - Non significant. *, **, $* * *$ indicate significance level at probability level of $5 \%, 1 \%$ and $0.1 \%$ respectively

$\mathrm{df}=$ degree of freedom; $\mathrm{RNPP}=$ average root number per plot; TFWPH=total fresh weight per hectare (tone); $\mathrm{MFWPH}=$ marketable fresh weight per hectare (tone); $\mathrm{UMFWPH}=$ unmarketable fresh weight per hectare (tone); $\mathrm{DWPH}=$ dry weight per hectare (tone); $\mathrm{ARD}=$ average root diameter (mm); $\mathrm{ARL}=\mathrm{average}$ root length $(\mathrm{cm})$.

Table 2. Means of sweet potato variety adaptation trial at Abaya in 2014 cropping season.

\begin{tabular}{|c|c|c|c|c|c|c|c|}
\hline Varieties & RNPP & TFWPH & MFWPH & UMFWPH & DWPH & ARD & ARL \\
\hline Awassa 83 & $57.7 \mathrm{~b}$ & $59.45 b$ & $50.60 \mathrm{~b}$ & $8.85 b c$ & $17.94 b$ & $46.6 \mathrm{ab}$ & $12.6 \mathrm{a}$ \\
\hline Beletech & $65.6 \mathrm{~b}$ & $41.61 b$ & $32.16 \mathrm{~b}$ & $9.45 b c$ & $11.01 \mathrm{~b}$ & $46.1 \mathrm{ab}$ & $7.1 \mathrm{c}$ \\
\hline Temesgen & $64.3 b$ & $28.17 b$ & $14.76 b$ & $13.41 \mathrm{~b}$ & $6.83 b$ & $28.7 b c$ & $10.9 \mathrm{ab}$ \\
\hline Belela & $2 \mathrm{c}$ & $0.88 \mathrm{~b}$ & $0.66 \mathrm{~b}$ & $0.22 \mathrm{c}$ & $0.21 \mathrm{~b}$ & $31.8 \mathrm{bc}$ & $7.9 \mathrm{bc}$ \\
\hline Kulfu & $2 \mathrm{c}$ & $1.85 \mathrm{~b}$ & $1.66 \mathrm{~b}$ & $0.19 \mathrm{c}$ & $0.31 b$ & $23.7 \mathrm{c}$ & $4.6 c$ \\
\hline Tula & $19 \mathrm{c}$ & $9.46 \mathrm{~b}$ & $7.17 \mathrm{~b}$ & $2.29 \mathrm{c}$ & $1.64 \mathrm{~b}$ & $41.2 \mathrm{abc}$ & $6.6 \mathrm{c}$ \\
\hline Local & $125.7 \mathrm{a}$ & $209.14 a$ & $176.85 \mathrm{a}$ & $32.30 \mathrm{a}$ & $71.39 \mathrm{a}$ & $55.9 \mathrm{a}$ & $11.7 \mathrm{a}$ \\
\hline $\mathrm{Cv} \%$ & 48.72 & 90.10 & 100.64 & 5.63 & 100.58 & 28.14 & 23.83 \\
\hline
\end{tabular}

RNPP=average root number per plot; TFWPH=total fresh weight per hectare (tone); MFWPH=marketable fresh weight per hectare (tone);

$\mathrm{UMFWPH}=$ unmarketable fresh weight per hectare (tone); $\mathrm{DWPH}=$ dry weight per hectare (tone); $\mathrm{ARD}=$ average root diameter (mm); $\mathrm{ARL}=\mathrm{average}$ root length $(\mathrm{cm})$. Means in the column with the same letter are not significantly different.

Table 3. Means of sweet potato variety adaptation trial at Abaya in 2015 cropping season.

\begin{tabular}{|c|c|c|c|c|c|c|c|}
\hline Varieties & RNPP & TFWPH & MFWPH & UMFWPH & DWPH & ARD & ARL \\
\hline Awassa 83 & $55.33 \mathrm{bcd}$ & $18.82 b c$ & $17.68 \mathrm{bc}$ & $1.14 \mathrm{ab}$ & $6.50 \mathrm{~b}$ & $72.67 a$ & $16.00 \mathrm{abc}$ \\
\hline Beletech & $29.00 \mathrm{de}$ & $3.53 \mathrm{~d}$ & $3.06 \mathrm{~d}$ & $0.47 b c$ & $0.92 \mathrm{c}$ & $59.33 b$ & $9.33 c$ \\
\hline Temesgen & $38.33 \mathrm{cde}$ & $13.84 \mathrm{bcd}$ & $13.46 \mathrm{bcd}$ & $0.38 b c$ & $4.76 b c$ & $68.67 \mathrm{ab}$ & $20.47 \mathrm{a}$ \\
\hline Belela & $123.67 \mathrm{a}$ & $24.10 \mathrm{~b}$ & $22.85 b$ & $1.25 \mathrm{ab}$ & $6.92 b$ & $70.47 \mathrm{ab}$ & $10.57 b c$ \\
\hline Kulfu & $62.67 \mathrm{bc}$ & $8.19 \mathrm{~d}$ & $7.54 d$ & $0.65 \mathrm{abc}$ & $2.90 \mathrm{bc}$ & $61.33 \mathrm{ab}$ & $10.37 \mathrm{bc}$ \\
\hline Tula & $18.33 \mathrm{e}$ & $3.24 \mathrm{~d}$ & $3.12 d$ & $0.12 \mathrm{c}$ & $0.96 \mathrm{c}$ & $68.67 \mathrm{ab}$ & $9.01 \mathrm{c}$ \\
\hline Local & $79.33 b$ & $46.65 a$ & $45.28 \mathrm{a}$ & $1.37 \mathrm{a}$ & $15.02 \mathrm{a}$ & $68.87 \mathrm{ab}$ & $18.47 \mathrm{ab}$ \\
\hline $\mathrm{Cv} \%$ & 29.87 & 38.99 & 40.43 & 65.86 & 46.78 & 10.65 & 34.33 \\
\hline
\end{tabular}

$\mathrm{RNPP}=$ average root number per plot; TFWPH=total fresh weight per hectare $(\mathrm{Kg})$; MFWPH=marketable fresh weight per hectare (tone);

$\mathrm{UMFWPH}=$ unmarketable fresh weight per hectare (tone); $\mathrm{DWPH}=$ dry weight per hectare (tone); $\mathrm{ARD}=$ average root diameter (mm); $\mathrm{ARL}=\mathrm{average}$ root length (cm). Means in the column with the same letter are not significantly different.

\section{Acknowledgements}

We thank Oromia Agricultural Research Institute for providing research fund. Science publishing group teams deserve special appreciation and sincere thanks for their unconditional assistance in editing and finalizing the paper from draft.

\section{References}

[1] International Potato Center (CIP). (1995). People centered research for sustainable production. Circular, Vol. 21 (21:1).
[2] CSA (Central Statistical Agency). 2014. Crop Production Forecast Sample Survey, 2013/14. Report on Area and Production for Major Crops (for Private Peasant Holdings 'Meher' season). Addis Ababa, Ethiopia.

[3] CTA Practical Guide Series, No. 6. 2007. Making sweet potato chips and flour. www.cta.int. Wageningen, The Netherlands.

[4] Dejene Takele Gebissa. Husbandry Practices and Utilization of Camel Products in Borana Zone of Southern Oromia, Ethiopia. ScienceResearch. Vol. 3, No. 4, 2015, pp. 191197. doi: $10.11648 /$ j.sr.20150304.16

[5] Dan. J., Mary. K. G., and Leigh A., (2013). Sweet Potato Value Chain: Ethiopia, EPAR (Evans School Policy Analysis and Research) Brief No 219, Wevans School of Public Affairs, University of Washigton 
[6] Emanna Gutu. 1990. Integrated approach for the control of sweet potato weevil, cylclaspuncticollis Bob (Coleoptera: curclionidae). In: proceedings of the 10th annual meeting of crop protection society of Ethiopia.

[7] Endale T., Terefe B., Mukgeta D., and Geleta L. 1994. Improvement study on enset and sweet potato. In: proceedings of second national horticultural workshop in Ethiopia. 1-3 Dec.1992. Addis Ababa Ethiopia.

[8] Gomez, K.A. and A.A. Gomez. 1984. Statistical Procedures for Agricultural Research. $2^{\text {nd }}$ edition. John Willey \& Sons Ltd., New York, USA.680pp.

[9] Paneque Ramirez (1991). Cultivation, Harvesting and Storage of Sweet Potato Products: Roots, Tubers, Plantations and Bananas in Animal feeding

[10] Purseglove, J.W. 1972. Tropical crops: Dicotyledons. Landon, longman.
[11] SAS (Statistical Analysis System) Software. 2009. Version 9.2. Inc.Carry, North Carolina, USA.

[12] Tesfaye T., Engida T., Aseffa T., Teshome A., Asfawu K., Yohannis G., Daniel M. 2011. Performance of medium and late maturing sweet potato germplasms in different agroecologies of Ethiopia. In: Proceedings of the 14th annual conference of the crop science society of Ethiopia. 28-29 Aprl 2011. Addis Ababa, Ethiopia.

[13] Woolf, J.A. 1992. Sweet potato: An untapped food resource. Cambridge university, Great bretain.

[14] Yared Dagne, Tewodros Mulualem, Asfaw Kifle. Development of High Yielding Taro (Colocacia esculenta L.) Variety for Mid Altitude Growing Areas of Southern Ethiopia. Journal of Plant Sciences. Vol. 2, No. 1, 2014, pp. 50-54. doi: 10.11648/j.jps.20140201.19 